DOI https://doi.org/10.18551/rjoas.2018-01.04

\title{
IMPLEMENTATION OF EMPOWERMENT PROGRAM FOR FISHERMAN SOCIETY: A THEORETICAL REVIEW
}

\author{
Mh Ismail \\ UIN Sunan Ampel, Surabaya, Indonesia \\ E-mail: ismailmh789@gmail.com
}

\begin{abstract}
This article aimed at describing and explaining a set of theoretical review on the implementation of human empowerment program for fisherman society. This article was composed using review of related literature method. The result of the review points out some interesting findings: policy is a set of actions that contain some agreements agreed by a person or a group of people to solve certain problem or to achieve certain goal; implementation of a policy involves a long process in implementing the program which should be oriented to achieve the predetermined goals as stated in the policy; fisherman society can be classified into several categories, such as traditional fisherman, subsystem fisherman, pure fisherman, recreational and commercial fisherman; traditional fisherman refers to those who seize resources from the nature using traditional tools, small capital, and relatively simple organization; empowerment is an effort to develop certain capability or potential by driving, motivating and raising society's awareness upon their own capability to be explored; society empowerment is an attempt to strengthen the dignity of certain society, to get themselves free from poverty or poor quality of life. In another word, empowerment is a program that helps a society to grow their ability and independence.
\end{abstract}

\section{KEY WORDS}

Policy, implementation, empowerment, fisherman.

The term 'policy' can be defined in various ways. This term is usually misused in referring to goals, program, decision, law, regulation, suggestions or major plan. The United Nations (1975) clarified that policy is a declaration of guidelines, orientations to cetain action, plans to implement certain program or actions (Wahab, 1997). Basically, policy is a guideline or procedure to do an action. This guideline might be quite simple or complex, general or specific, broad or limited, overt or covert, loose or detailed, qualitative or quantitative, public or private. In line with the definition of a policy made by The United Nation, a policy is "a proposed course of action of person, group, or government within anak given environmnent providing abstacles and opportunities which the policy was proposed to utilize and overcome in an effort to reach an goal or relizean objective or purpose"(Islami, 2000). It is also defined that a policy is "A purposive course of action followed by action or set actors in dealing with a problem with a problem or metier of concern" (Wahab, 1999). Another expert explained that "A policy ...consist of web of dicisions and actions than allocatevalues"(Wahab, 1999).

Besides those three definitions mentioned above, there are other defintions with slightly different essense in defining a policy. It can be inferred from those three definitons that basically, a policy consists of several elements: 1) a set of actions; 2) actions are performed by a person or a group of people; 3 ) there are solutions available for problems that occur, 4) there is certain goal.

From the combination of those four elements, it can be defined that a policy is a set of actions that reflects agreements made by a person or a group of people used to solve certain problems and to reach certain goals.

Even if the term policy can be used as a general term, usually it is more frequently and broadly used to refer to actions or programs made by a government within the context of a nation (public policy). Some experts have made some definitions of a public policy. One of which stated that public policy "is whatever government choose to do or not to do". Furthermore, it is highlighted that a government should set the objetives of certain programs 
before implementing them. Public policy should be made upon clear public interest since it is not merely subjective ideas of certain government or officials. In addition, any undone action can still be considered as public a public policy even if it is not made by a nation since an undone action might have equal effect with certain completed action (Islamy, 2000).

A similar view was proposed by Dye in which it is stated that a policy "....is what government say and do, or not do,. It is the goals or purposes of government programs...." (Anderson. 1979). Another expert stated that "public policies are those developed by government bodies and officials" (Anderson. 1979). Lastly, the meaning of public policy is depicted as follows: "A set of interrelated decisions taken by a political actor or group of actor concerning the selection of goals and the means of achieving them within a specified situation where these decisions should, in principle, be within the power of these actors to achieve" (Wahab. 1998).

Regarding to those defintions, basically a public policy refers to any actions made based on public interests by considering social values that apply. Public administrators should always bring public interests into their polical discourse in order to prevent them from taking any decision based on their subjective interests. Therefore, it can be concluded that public policy is a set of actions done or undone by a government to achieve certain goal that carries public interests.

Based on various definition of public interests, there are some important elements of a public policy, which are: initially, public policy is a decision to implement certain action made by the government; public policy is not only declared, but it should also be implemented as a real action; public policy to do or not to do certain action is arranged based on certain reasons and objectives; any public policy should be made for public interests. (Islamy. 2000).

Implementation of a policy is a process to conduct a plan related to the policy made by government which is aimed at achieving certain objectives. The implementation process can be started when the objectives have been clearly determined along with detailed procedure and determination of funding source to reach the objectives. There are four key aspects in the implementation of a policy: who are being involved in the implementation, the administrative processes, and obedience upon the policy, effects and impacts of the implementation of a policy (Anderson. 1979).

In a broader context, implementation of a policy is a legal administrative tool that involves several actors, organizations, procedure, and technique in working collaboratively to run a policy in order to achieve its objectives. From another side, implementation is a complex phenomena which can be understood as "those actions by public or private individuals (or groups) that are directed at the achievement of objectives set forth in prior policy decisions". Policy implementation is a crucial phase of a policy since it is not only involved with its mechanism, explanation, politics, prodecures, bureaucracy, but it also concerns aspects related to conflicts, decisions, and who obtain something from the implementation of a policy. Policy implementation might be more important than the policy making. Policies are only well-achieved expectations or ideal plans if it is not implemented (Wahab. 1998).

Policy implementation functions as a way to form a complex relationship that allows the objectives or targets of a policy to be obtained as an outcome. Unfortunately, seen from the perspective of public policy study, it has to be admitted that only in the last decade, social scientists especially politics experts began to grow attention to the the process of policy implementation and the acceptance to consider it as an integrative part of a policy making process (Wahab. 1998).

The process of a policy implementation should be well-controlled. Thus, it is inappropriate to assume that the implementation of a policy can run well without any obstacle. It should be taken into account that the implementation of a policy is a dynamic process which involves various factors. A legalized policy has a legal legitimacy from the legislative institution which should be taken into actions by the bureaucracy.

Shortly, policy implementation means to provide the means for carryin gout and to give practival effect. Based on this view, policy implementation is considered as a process to run a policy which are usually in the form of law, government rule, regional regulation, court 
decision, executive orders of president's order.

Therefore, it can be concluded that policy implementation process does not only involve actions of the administrative institutions in charge for the program to grow obedience of the targeted group, but it also deals with a network of political and social groups which might either directly or indirectly influence the behavior of any parties which are involved in the program. Eventually, it might lead to the intended effects or even unintended effects (spillover/negative effects).

To make a policy implementation more effective, ones have to consider these two characteristics of a policy implementation:

Policy implementation is self executing. It means that by the time the policy is made, the policy is automatically implemented. For instance, the policy to acknowledgement of a nation to the sovereignity;

Policy implementation is non-self executing. It means that a policy can only be implemented when some institutions in charge act for it.

Theoretical framework of a policy implementation should start from the consideration of the objectives and the targets of the policy. The implementation of a policy might be different from implementation of other policies depending on the characteristics of the policy. Different decision makes different charactertistics, structures and relationship among the factors that influence the policy. Thus, the impelementation of the policy will be different. Policies can be seen from two perspectives; the amount of changes a policy brings to achieve certain objectives and how the implementation of a policy runs. A change is the most important indicator of a policy implementation since it involves these two following aspects.

Implementation is affected by how far a policy deviates from previous policies. In the context, incremental changes tend to raise positive responses rather than drastic changes. Incremental changes which result from incremental decisions are actually remedials that are directed to complete the already existing social gap rather than promoting the objectives of the policy in the future. This insight is different from the one that is made ou of rational decision which is mainly oriented to create major and fundamental changes. As the result, the chance to spark conflicts and disagreements is higher.

Implementation process is affected by the organizational changes that are required. Effective implementation can be achieved if an organization is not required to create drastic reorganization. Failures in conducting social programs are mostly caused by the increasing number of requirements that should be fulfilled within the already existing structures and administrative prodecures.

A successful implementation requires a good working system which involves four parameters, which are:

Overtime coordination. Coordination should not be limited to certain time in order to make it optimal and and informal;

Regular coordination. Coordination and monitoring should be clearly scheduled and agreed by the parties that are involved in the process;

Detailed logistics and fixed schedule. Implementation of a certain policy requires enough supply of logistics;

Clearly determined job descriptions. It is necessary to create detailed run down in order to make monitoring to each organizational unit easier (Parsons. 1997).

It takes effective approach to a system that emphasizes on strengthening the teamwork and clarifying the objectives, structures, theoretical framework and implementation to make a policy implementation successful.

Effective implementation requires these six conditions: clear and consistent objectives in order to provide clear evaluation standards and legal resources; rational cause-effect relationship that is able to strongly present how a new policy brings positive changes; legalized structure to provide the needs of the actors who are in charge of implementing a policy and to provide the needs of certain groups involved in the policy as the targets of the policy; experts should be involved in the implementation of a policy to effectively achieve the objectives of a policy implementation; supports from the parties involved in the program and supports from the officers in the legistative and executive institutions; there has to be some 
positive socio-economic changes made by a policy that should not decrease the supports from politicians or raise any negative effects to the already settled mechanisms that support the policy.

Empowering fisherman society. Traditional fisherman are fisherman that use traditional tool in fishing, need small amount of capital and apply a relatively simple organization. In the daily basis, traditional fisherman mainly focuses on the fulfillment of their subsistence. It means that the profit from their fish sale is used to fulfill their daily necessities such as food instead of investing it back to enhance their fishing method. Usually, traditional fisherman is from poor families which are firstly affected by moderninzation and economic crisis (Satria dalam Suhartini, 2005).

Traditional fishermen depend on the condition of the nature. A long dry season does not only give them small fish seizures, but also put them into poverty and force them to request for some loan for living. The limited resources owned by traditional fisherman are the obstacles for them to reach higher social welfare and to get themselves free from poverty (Suyanto 1996).

Widodo (2006) grouped fisherman into four types:

Subsistence fishers, referring to fisherman that seize fish to fulfill their daily necessities;

Native/indigenous/aboriginal fishers are fisherman that have similar characteristics to subsistence fishers but they have the legal right to do small-sclae commercial fishing;

Recreational fishers are fisherman who do fishing as hobby or sports;

Commercial fishers are the ones who seize huge amount of fish for commercial objective or to be sold in domestic market as well as to export them abroad. Commercial fishers are grouped into huge-scale fishers and small-scale fishers.

Fisherman can also be grouped based on the terminology of the fishing intensiveness including: fulltime fisherman, referring to fisherman who depend their lives on fishing; parttime fisherman, the ones who do not completely depend their lives on fishing (they have other earnings from other activities).

Fisherman can also be group based on the ownership: owner refers to the ones who own fishing resources such as ship and fishing tools; fishing crews, those who are paid to do fishing using the fishing resources provided by an owner.

Accoding to Bailey in Widodo (2006), small-scale fisheries industries have these characteristics.

Small-scale fisheries industries are generally dependant to marine resources as their main job and their activities can be done along coastal lines. With this condition, good management of marine and fisheries is the key to the sustainable marine resource and its utilization.

Fisherman in this group has limited access to other jobs and most of them earn quite low income. Scarcity of fish in the ocean direcly affects the quality of their life.

Small-scale fisheries industries also utilize technology such as ship and seizure tools but at a limited number and limited capacity. Hence, developing the industries and expanding their fishing areas to open sea would be difficult to conduct.

Small-scale fisheries industry is mostly located far from the central city in which both political and economic activity occurs. As the implication, fisherman have low bargaining position which appears to be a weakness since they have to compete with bigger-scale fisherman who employed productive devices such as purse seine, trawl and fishpond. Smallscale fisheries industries are very much vulnerable to get affected by extern factors that it is necessary to build certain protection system. The socio-economy status of fisherman is classified into: rich and wealthy; middle class; poor and very poor (Kusnadi, 2002).

Suharto (2005) stated that empowerment refers to the attempts to enhance ones' ability, especially ability of the weak groups to be able to; (a) fulfill their primary necessities and free from hunger, illiteracy, and illness; (b) utilize any productive resources that might be used to increase their income which allows them to buy any necessary goods or services; (c) participate in the process of nation's development and in any discussion to determine decisions related to them. 
In line with the statement, empowerment is an answer to the disempowerment reality. Weak and poor people do not possess any adequate strength. Weak people are those who have no strength from the beginning and those who somehow lost their strength. People who lost their strength have experienced certain process that made their strength taken away from them (Pambudi, 2003).

Ife in Suharto (2005) explained that empowerment consists of two essential key word; power and powerless group. In this context, power does not only relate to political power, yet it refes to any power possed by a person or some people to have personal choice or life chances to choose certain life style, place to live, or occupations; determination of their necessities based on their own preferences; ideas and ways to express their ideas within a forum or discussion without any pressure; ability to use, influence or access to any social program such as social welfare department, education, health sercices; ability to mobilize formal, informal or society resources; conduct economic activities and have the ability to manage production, distribution, exhanges or services; reproduction; the ability to access good health care for giving birth, child care, education and socialization.

Empowerment is an effort to dvelop a potential by driving, motivating and raising society's awareness upon their potential to be furthermore explored (Kartasasmita, 1996).

Empowerment process is a sustainable process one has to go through their life (on going proess). Hogan in Adi (2002) explained that individual empowerment is a relatively long process that keeps running throughout one's life which is obtainef from one's life experience. It is not an end-state, but a process that all human being experience.

Suharto (2005) explained that power is related to influence and control. This view assumes power as a fixed entity that cannot be changed. However, it is believed that power is not only limited to this view. Power is always present in any social relationship among human since power is created upon social relationship. Thus, it makes sense if power is changeable. Within this belief, empowerment is seen as process to change certain state. In addition, empowerment depends on; (1) the changeability of power. If the power is absolute, empowerment cannot occur. (2) Power is expandable which implies that power is not static; instead it is a dynamic state.

Regarding to those views, empowerment is a process and an objective at the same time. As a process, empowerment refers to a set of action to srenghten a power or to give power to powerless people including people who are poverty-stricken. As an objective, empowerment refers to the state or an expected result of a social change, empowered society, society with adequate knowledge, power and ability to fulfill both their physical needs and economical needs, as well as social needs such as self esteem, freedom to show opinion, proper occupation, ability to participate in social activities and independence. Empowerment as an objective has been misused as an indator of empowerment as a process.

Payne dalam Cook \& Macaulay (1997) stated that empowerment process is meant "...to help client gain power of decision and action overtheir own lives by reducing the effect of social or personal block to exercising existing power, by increasing capacity and self confidence to use power and by transfering power from the environment to client".

Society empowerment can be conducted in a sequential order which consists of three phases; (1) intial phase, (2) participatory phase, and (3) emansipatory phase (Pranarka dan Prijono, 1996).

In the initial phase, the process is run by the government for the society. In this step, the society plays a passive and dependant role by only receiving and performing what is instructed by the government. Then, in the participatory phase, the government still provides the facitilites but the society is actively involved to reach independence. Eventually, in the emancipatory phase, the society run the program themselves, by themselves, for themselves and the government gives full support along with the society. In this mature phase, the society has grown complete awareness of their autonomous energy, and they have developed their potentials and understanding how to utilize their potentials.

Emancipatory phase is the peak of the society empowerment program. At this point, the society has grown adequate ability in conducting any programs or activities to meet their 
own expectations or necessities. In order to come to this point, there are mainly two conditions to fulfill which include the requirements in planning the development programs and the requirements in implementing the programs.

The three phases of society empowerment sometimes do not run in order. Some society might have grown adequate capability to start the process from the participatory phase.

An empowered society has some characterisitcs; democratization, equality between the society and the government, freedom of speech, freedom to be creative, freedom to make plans, freedom to manage local assets, rights to monitor government's performance, rights to enjoy the results of the society's work in achieving certain objectives of the society empowerment program (Suhendra, 2006).

Efforts to enhance society's life quality cannot be simply done by providing fund or charity programs since those kinds of actions might create bias which broadens the social gap among the society stratifications. Moreover, charity programs that provide full fund put poor families as the objects of the program and make them become highly dependant to the government. This way, poor families become weaker. Therefore, empowerment program is an appropriate program to run.

Empowerment program refers to a set of efforts that aim at enhancing human's quality of life and improving the condition of some unfortunate people who are being stricken by poverty and backwardness. In another word, empowerment is attempted to improve society's capability and independence.

This ideal concept of empowerment puts empowerment program in a strategic position in every nation's development program. Stakeholders' consting of the government, nongovernment parties and the society might out of the sudden put empowerment label in their programs. This condition is expected to trigger positive effects for the program. However, in administering a program, problems might appear. Therefore, it is necessary to determine strategic steps in empowering the society, in which empowerment program is utilized as antipoverty program in Indonesia that can be administered through these following steps proposed by Tjokrowinoto (2004).

First, empowerment program is a requirement of anti-poverty program. Empowerment program emphasizes the feeling of being impotential experienced by poor families when they have to deal with unfavorable socio-politic structure. A concrete action can be started by raising society's critical awareness of the role of a society in the social-politic structure around their area. Without having adequate critical awareness, poor families remain powerless and they might grow the tendency to give up on their fate.

Second, after a society has raised adequate critical awareness, people would make certain attempts to cut off any exploitative actions done to poor people. Abolishing exploitative actions can be done through a thorough reformation on social aspect, culture, and politics. In short, we can let critical awareness grow within a society and the society should be let to do reorganization in order to increase their productivity and improve their quality of life.

Third, it is important to grow egalitarian in a society and enhance the understanding that poverty is not an end-fate, but it can be changed through social reconstruction. Poverty is changeable, and the one who can change it is the society itself. Poverty and social gap is not a fate given by the God, but it is the product of social contruction made by the society. the action.

Forth, implementing the development plans by getting poor families fully participated in

Fifth, poor families need education and development of social and culture. Aside from the necessity to bring structural change, poor families should also grow positive values such as proper ways in planning a good life, optimism, changing their life style, improving their productivity and their quality, etc.

Sixth, infrastructure redistribution should be made equal and even. Even though the previous five steps can be achieved without adequate support of propoer infrastructure, but poor families generally do not have access to improve their economic condition, and they do not have any access to other aspects of life. 
According to Schuftan (1996), society empowerment can be implemented using these four approaches:

- Service delivery which is characterized by direct contact with the society which appears to be the main cause of failures in implementing a development program.

- Capacity building which can be approached by improving society's knowledge, understanding, awareness and skills to optimize their capacity by using any available facilities to prevent the society development from failures.

- Advocacy which can be approached by determining a dynamic process in reaching a consensus and plans in implementing certain action.

- Social mobilization which should be approached by involving the society to actively participate in making assessment, analysis and actions within the implementation process of a program to find the fundamental factor that causes failures in a society empowerment program.

Kusnadi (2007) proposed some qualitative indicators of a well-empowered fisherman society, including:

Fulfillment of socio-economic welfare of individuals, families and society which can be seen from these following indicators: well-developing economic independence and wellenhanced entrepreneurship, increasing amount of saving and investment, well-fulfilled primary and secondary needs in the most optimal and sustainable way, high quality human resources;

Economic institutions function optimally and economic activities run in a stable and continue way;

Social organizations run their functions well as the insturments of regional development;

Easier access for the society toward economic resources; information, capital, market and technology;

Higher participation of the society in taking decision related to any development programs run in coastal areas and better critical awareness toward development issues in their area;

Coastal areas should be developed as the central of regional and national economic development that are able to attract more investment.

Furthermore, Kartasasmita (1996) mentioned three ways to implement a society empowerment program, which are:

Creating favorable and supportive environment to enhance a society's potetials. This view regards an assumption that each individual and group has certain potentials which can be improved. The real essesnce of independence and empowered society is to raise awareness and belief that a society has the ability and potential to organize them by exploring individuals' potential.

Strengthening the potential or capability of a society by implementing real actions, sharing ideas, providing physical facilities (drainage system and electricity) as well as social facilities (schools and health care) that are accessible for anyone even those from the lowest social class. Accessible facilities such as financial institutions, training center, and marketing consultant available in rural areas empower the society.

Protecting and defending the interests of poor society. Empowerment program should prevent the number of poor families from growing or getting marginalized by the upper class. Therefore, empowerment program should provide protection and take sides with the lower class society.

Society empowerment is not limited to only economic development, but it taps on politic, social, and culture development. Thus, the society will eventually have higher bargaining position and high competitiveness to compete within regional or national market. The paradigm of society empowerment proposed in this article aims at uplifting the current condition which rather centralized (top down) by giving broader opportunities for poor society to plan and implement their own empowerment programs. They are also given authority to manage the funding provided by the government and non-government institutions to fund their own programs (Sutrisno, 1995). 


\section{CONCLUSION}

Policy is a set of actions that cosist of decisions agreed by certain group of people to solve certain problem and to achieve certain objective. Policy implementation is the process to administer a decision made by the government to reach the objectives of the policy.

Fisherman society can be grouped into: traditional fisherman, subsistence fisherman, native fisherman, recreactional fisherman and commercial fisherman. Traditional fisherman refers to fisherman community that utilizes traditional tools in seizing fish, use small amount of capital and apply a relatively simple organization in doing their fishing activities.

Empowerment refers to an attempt to improve certain resource or potential owned by a society by driving, motivating and raising the awareness of the society toward its own capability be optimally explored. Society empowerment is an effort to uplift the condition of certain unfortunate society who is being stricken by poverty.

\section{REFERENCES}

1. Perserikatan Bangsa-bangsa (1975).

2. Wahab abdul solichin, 1997. Evaluasi kebijakan Publik. Penerbit FIA

3. Islami, 2000. Islamy, M. Irfan. 2000. Policy Analysis: Seri Monografi Kebijakan Public. Universitas Brawijaya. Malang.

4. Islamy, Irfan. 1998. Agenda Kebijakan Reformasi Administrasi Negara. Pidato Pengukuhan Jabatan Guru Besar. Fakultas IImu Administrasi Universitas Brawijaya. Malang. 1 Agustus 1998.

5. Wahab abdul solichin 1999. Reformasi Pelayanan Publik: Kajian dan Persfektif Teori Governance. Pidato Pengukuhan Guru Besar dalam IImu Kebijakan Publik pada Fakultas IImu Administrasi Universitas Brawijaya. Malang tanggal 30 Oktober 1999.

6. Wahab abdul solichin 1998. Ekonomi Politik dan Bisnis Indonesia Era Orde Baru. Universitas Brawijaya. Malang.

7. Wahab abdul solichin. 2002. Masa Depan Otonomi Daerah: Kajian Sosial, Ekonomi, Dan Publik untuk Menciptakan Sinergi dalam Pembangunan Daerah. SIC.unibraw dan IKIP Malang.

8. Anderson, Richard E.; Darkenwald, Gordon G.1979 Participation and Persistence in American Adult Education. Implications for Public Policy and Future Research from a Multivariate Analysis of a National Data Base. Direction Papers in Lifelong Learning. Collected Works - Serials; Reports - Research

9. Parsons, W. 1997. Poublic Policy: An Introduction to the Theory and Practice of Policy Analysis. Queen Mary Westfield Collage University. London.

10. Suhartini Rr, et. al. (eds). 2005. Model-Model Pemberdayaan Masyarakat, Pustaka Pesantren. Yogyakarta.

11. Suyanto, Bagong (eds). 1996. Perangkap Kemiskinan, Problem Dan Strategi Pengentasannya. Airlangga dan University Press. Surabaya.

12. Widodo, J dan Suadi. 2006. Pengelolaan Sumberdaya Perikanan Laut, Gadjah Mada University Press

13. Kusnadi. 2002. Konflik Sosial Nelayan: Kemiskinan dan Perebutan Sumber daya Perikanan. LKIS. Yogyakarta.

14. Suharto, Edi. 2005. Membangun Masyarakat Memberdayakan Rakyat: Kajian Strategis Pembangunan Kesejahteraan Sosial \& Pekerjaan Sosial. PT. Refika Aditama. Jakarta.

15. Pambudi, Himawan S, et al. 2003. Politik Pemberdayaan: Jalan Mewujudkan Otonomi Desa. Lappera Pustaka Utama. Yogyakarta.

16. Kartasasmita, Ginandjar. 1997. Administrasi Pembangunan: Perkembangan Pemikiran dan Praktiknya di Indonesia. Pustaka LP3ES. Jakarta.

17. Adi, Isbandi Rukminto. 2002. Pemikiran-Pemikiran Dalam Pembangunan Kesejahteraan Sosial. Lembaga Penerbit Fakultas Ekonomi Universitas Indonesia. Jakarta.

18. Cook, Sarah And Steve, Macaulay. 1997. Pemberdayaan Yang Tepat. PT. Elex Media Komputindo. Jakarta. 
19. Prijono, O, S dan Pranarka A.M.W. 1996. Pemberdayaan: Konsep, Kebijakan dan Implementasi. CSIS. Jakarta.

20. Suhendra, K. 2006. Peranan Birokrasi dalam Pemberdayaan Masyaraka., Alfabeta. Bandung.

21. Tjokrowinoto, Moeljarto. 2004 cetakan V. Pembangunan: Dilema Dan Tantangan, Pustaka Pelajar. Yogyakarta.

22. Scuftan, Claudio. 1996. The Community Development Dilemma: When Are Service Delivery, Capacity Building, Advocacy And Social Moblisation Really Empowering. Community Development Journal. Vol. 31 (3). July, 1996.

23. Kusnadi. 2002. Konflik Sosial Nelayan: Kemiskinan dan Perebutan Sumber daya Perikanan. LKIS. Yogyakarta.

24. Soetrisno, Loekman, 1995. Menuju Masyarakat Partisipatif. Yogyakarta: Penerbit Kanisius. 